\title{
Genetic Structure and Gene Flow of Moss Sanionia uncinata (Hedw.) Loeske in Maritime Antarctica and Southern-Patagonia
}

\author{
Ingrid Hebel ${ }^{1 *}$, Maria Carmen Dacasa Rüdinger ${ }^{2}$, Ricardo A. Jaña ${ }^{3}$ and Joaquin Bastias ${ }^{4,5}$ \\ ${ }^{1}$ Plant Biotechnology Lab, Department of Agriculture and Aquiculture, University of Magallanes, Punta Arenas, Chile, ${ }^{2}$ Wood \\ and Forestry Competence Centre, Forest Genetics and Forest Plant Breeding, Public Enterprise Sachsenforst, Pirna, \\ Germany, ${ }^{3}$ Scientific Department, Chilean Antarctic Institute, Punta Arenas, Chile, ${ }^{4}$ Departamento de Geologia, Universidad \\ de Chile, Santiago, Chile, ${ }^{5}$ Department of Earth Sciences, University of Geneva, Geneva, Switzerland
}

\section{OPEN ACCESS}

Edited by:

Su Wang,

Beijing Academy of Agricultural and Forestry Sciences, China

Reviewed by:

Heinjo During,

Utrecht University, Netherlands

Lin Wang,

University of Hong Kong, Hong Kong

*Correspondence:

Ingrid Hebel

ingrid.hebel@umag.cl

Specialty section:

This article was submitted to

Population and Evolutionary

Dynamics,

a section of the journal

Frontiers in Ecology and Evolution

Received: 13 April 2018

Accepted: 12 September 2018

Published: 09 October 2018

Citation:

Hebel I, Dacasa Rüdinger MC, Jaña RA and Bastias J (2018) Genetic

Structure and Gene Flow of Moss

Sanionia uncinata (Hedw.) Loeske in

Maritime Antarctica and

Southern-Patagonia.

Front. Ecol. Evol. 6:152.

doi: 10.3389/fevo.2018.00152
Bryophytes are a major component of vegetation in ice-free coastal regions of Antarctica. Sanionia uncinata (Hedw.) Loeske is distributed from northern and central Maritime Antarctica to Marguerite Bay in the southern part of this biome where it occurs sparsely. Production of sporophytes is rare for $S$. uncinata in Antarctica, thus a high level of genetic uniformity among populations is expected (Lewis Smith, 1984). Several ice advances and retreats events in last thousands of years in Patagonia and Antarctica could have driven different processes of speciation at fine scale or triggered genetic differentiation among populations, leading to unique genetic populations. A few studies have analyzed the genetic structure of mosses in Antarctica, but none in Maritime Antarctica or in the nearby zones such as southern Patagonia. Based on Amplified Fragment Length Polymorphism (AFLP) and grouping analysis, we determined levels of intra/and inter-population genetic diversity of $S$. uncinata in sites of this region. The results revealed that gene diversity within populations was low and that populations did not have significant genetic differentiation. Also, no correlation was found between genetic variability and geographic distance $\left(R^{2}=0.031\right)$. However, we distinguished two groups of populations. One of them clustered populations with low values of genetic diversity. The other one was made out of populations showing much higher genetic diversity. Cluster 1 was the most geographically widely distributed covering populations from northern part of southern Patagonia to southern part of studied populations in Maritime Antarctica. Cluster 2 had the highest level of polymorphism, but spatially is very restricted to four populations in the Maritime Antarctica and southern Patagonia. We found substructures in some populations of the Maritime Antarctica such as in the Coppermine, Byers and Suffield populations. The underlying causes of this subdivision could be the asexual reproduction and significant abiotic factor affecting the presence of this moss species, but also the autoecious condition of this species. The importance of results is the concept of genetic connectivity among bioregions of South Patagonia and Antarctica suggesting additionally this interaction may have occurred repeatedly after the LGM, resulting in the vegetation that grows in Antarctica today.

Keywords: gametophytes, ancestral origin, genetic diversity, fine-scale, HYSPLIT 


\section{INTRODUCTION}

Bryophytes are a major component of the vegetation in ice-free coastal regions of Antarctica such as the South Shetland Islands (SSI) and in sites in the western sector of the Antarctic Peninsula (AP). A total of 117 species of mosses have been identified in these regions (Ochyra et al., 2008; Ellis et al., 2013a,b; Sollman, 2015). A large number of bryophyte species have also been identified in sectors of Patagonia, the sub-Antarctic region of South America. Sanionia uncinata (Hedw.) Loeske is widely distributed in the northern and central maritime Antarctic, with some isolated occurrences in Marguerite Bay in the southern part of this biome (Ochyra et al., 2008). S. uncinata has also been found in periAntarctic islands and archipelagoes, as well as in the west and east ice-free areas of the Antarctic Peninsula. In Chile, S. uncinata is found from Regions IX to XII, this last region belonging to Patagonia (Larraín, 2007). In many cases S. uncinata covers large extensions in valleys and beaches, alone or in association with other bryophyte species (Torres-Mellado et al., 2011). It grows also in free ice areas such as moraines, peri-glacier geoforms and on newly exposed areas at glacier fronts, tolerating relatively unstable conditions, severe dehydration and minimum nutrient concentrations.

The oldest evidence of this species in the Antarctic after the last glacial maximum (LGM) was found in subfossil peat on King George Island, which has been dated by radiocarbon method to be $4,950 \pm 140$ years old (Birkenmajer et al., 1985). Hedenas (2012), suggested that Sanionia became extinct during the LGM, based on the low number of haplotypes found in most of the sub-Antarctic islands outside the region from southernmost South America to the Antarctic Peninsula. The results of that study indicated that the presence of Sanionia is relatively young, so that it had little time to diversify; its distribution is best explained by dispersal of clonal gametophytes, the germination of diaspores dispersed by the rain and predominant western winds in the Southern Hemisphere, which has been also shown for other mosses such as Leptobryum wilsonii (Kato et al., 2013). In spite of this, several previous molecular genetic studies on moss species in Antarctica have demonstrated high or moderate genetic variability within clumps with some spatial relationships on meter to kilometer scales indicating that there is some clustering of populations (Selkirk et al., 1997, 1998; Skotnicki et al., 1998a,b,c, 1999a,b; Dale et al., 1999; Clarke et al., 2009).

It is known that spore germination and establishment of mosses are limited by local environmental conditions, such as edaphic conditions and light intensity (Caners et al., 2009).The production of sporophytes for some bryophyte species in Antarctica is rare, as is the case of S. uncinata, so that high levels of genetic uniformity among populations are expected (Lewis Smith, 1984). However, repeated cycles of advances and retreats of ice coverage in Patagonia and Antarctica during the last thousands years could have led to processes of speciation at a fine scale and genetic differentiation among populations, resulting in unique populations from a genetic point of view in these areas. To date there have been few studies on the genetic structure of mosses and that few have focused mainly on mosses in the Ross Sea region (west Antarctica), rather than on Maritime
Antarctica or related zones such as southern Patagonia. In this study we analyzed the fine-scale genetic diversity, population differentiation and population subdivision of $S$. uncinata in populations in Maritime Antarctica and southern Patagonia. We discuss possible causes of the genetic structure and patterns of gene flow and (re)colonization in these regions and link these events to the reproductive dynamics of the species.

\section{MATERIALS AND METHODS}

\section{Sampling Areas}

A total of 17 populations in maritime Antarctica and southernPatagonia were sampled (Table 1). The sampled sites are shown in Figure 1.

The geomorphology of both Antarctica and Patagonia is largely dominated by the effects of glaciers on the landscape. During the LGM, the Antarctic Peninsula, the South Shetland Island and Patagonia were covered by an extensive ice sheet. Several authors have suggested that soil generation began in these regions after the LGM, ca. 16-9 thousand years ago (Navas et al., 2008; Pfeiffer et al., 2010). The weathered bedrock that formed the soil at the S. uncinata sampling sites had different geological origins, depending on the location. The soils had a volcanic and volcaniclastic origin at several sites in King George Island (Smellie et al., 1984), Coppermine on Robert Island (Smellie et al., 1984), and Crooker Lake on Deception Island (Martí et al., 1996). The geology of Patagonia broadly consists of a volcanic to volcaniclastic and sedimentary succession assigned to the early to mid-Mesozoic (Fildani et al., 2008).

As described previously in other studies (Skotnicki et al., 1999b; Bijlsma et al., 2000; Van Der Velde and Bijlsma, 2000), samples were separated by $20 \mathrm{~m}$, and consisted of several shoots, collected from moss pads close to streams, roads, Antarctic stations and glacier boundaries, both in the Antarctic Specially Protected Area (ASPA) and open access areas. A total of 281 samples of the studied species are stored at the Instituto de la Patagonia Herbarium (Access code HIP 15068-HIP15349).

\section{DNA Extraction and AFLP Protocol}

One shoot from each sample was washed repeatedly with distilled water. Then, DNA was extracted using an E.Z.N.A ${ }^{\circledR}$ High Performance DNA Kit (OMEGA bio-tek ${ }^{\circledR}$, Doraville, GA, USA) and observed after separation on $1 \%$ agarose gels after staining with Gel Red (Biotium Inc. Fremont, CA, USA). The AFLP fingerprinting was performed according to the original protocol (Vos et al., 1995). Extracted DNA (50$500 \mathrm{ng}$ ) was digested with EcoRI and Tru9I for $2 \mathrm{~h}$ at $37^{\circ} \mathrm{C}$ and ligated with two adaptors for $3 \mathrm{~h}$. Preamplification is usually done with $+2,+1$, or +0 primers or combination thereof. Most studies use $+1 /+1$, but $+0 /+2$ worked also well in plants (Weising et al., 2005). For small genomes it is recommended to use shorter selective primers, taking into account if they are "rare" cutters or "frequent" cutters (Paun and Schönswetter, 2012). Preamplification was carried out in a Maxygene thermal cycler (Axygen, Tewksbury, MA, USA) using primers for EcoRI+0 (E, 5'-GACTGCGTACCAATTC-3') and MseI+1 (M, 5'-GATGAGTCCTGAGTAAA-3'). The quality 
TABLE 1 | Results of genetic diversity analyses.

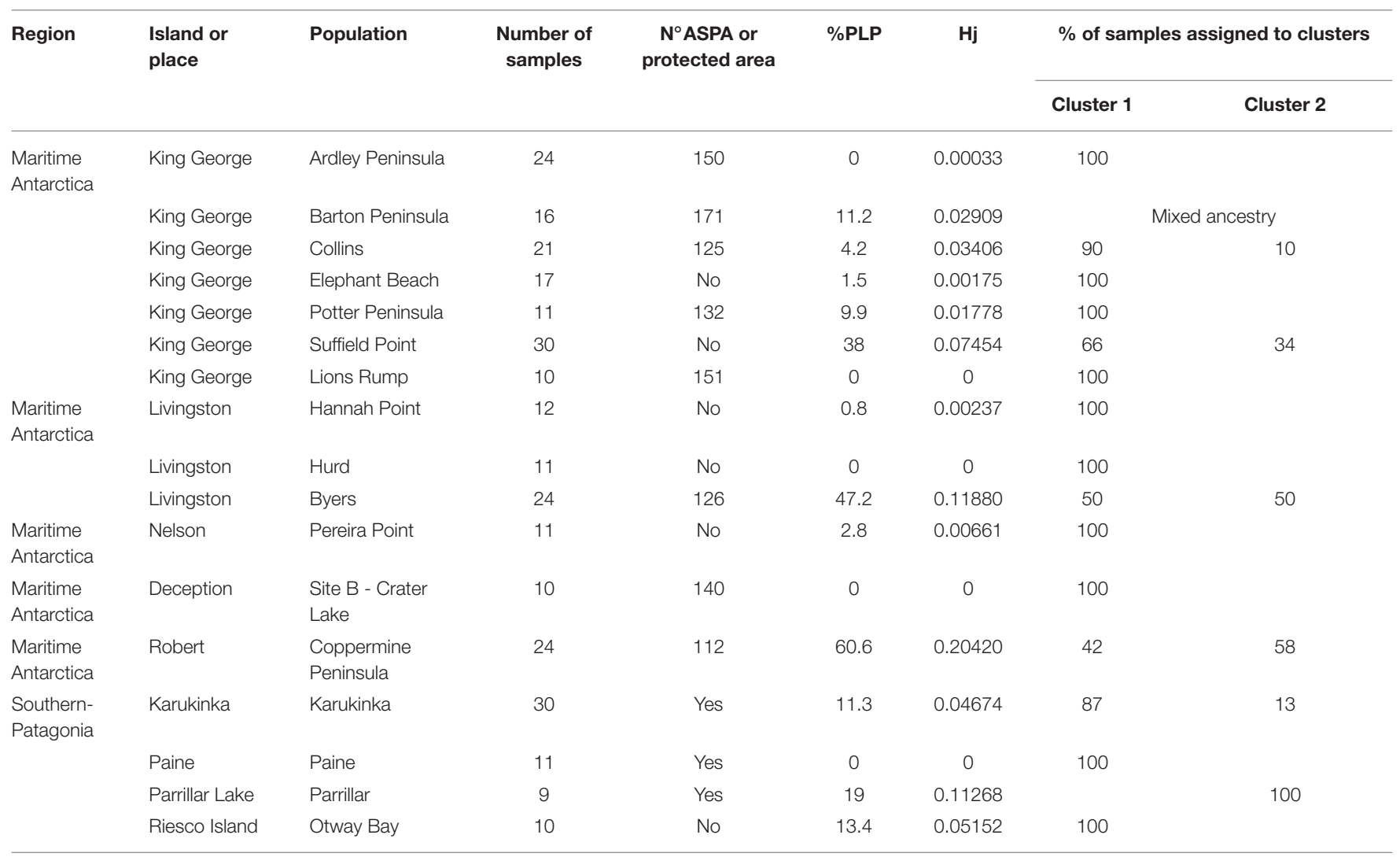

ASPA, Antarctic Specially Protected Area; \%PLP, proportion of polymorphic loci at 5\% level; Hj, expected heterozygosity under H-W proportion. Clusters 1 and 2 are the cluster defined bY STRUCTURE.

and quantity of the pre-amplified products were determined by separation on $1 \%$ agarose gels after dilution (1:9) with $\mathrm{ddH}_{2} \mathrm{O}$. Fifteen selective primer combinations were checked to determine whether they produced polymorphic bands with sufficient reproducibility and clarity. We finally selected three primer combinations for selective amplification: EcoRI+AAGG and MseI+ACGG; EcoRI+ACA and MseI+AGC; EcoRI+ACA and MseI+CAG. Each PCR was performed in a $20-\mu \mathrm{L}$ reaction mixture containing $3 \mu \mathrm{L}$ diluted pre-amplification product, $0.25 \mu \mathrm{M}$ E-primer, $0.3 \mu \mathrm{M}$ M-primer, $10 \mathrm{mM}$ Tris- $\mathrm{HCl}(\mathrm{pH}$ 8.0), $1.5 \mathrm{mM} \mathrm{MgCl}_{2}, 0.2 \mathrm{mM} \mathrm{dNTP}$, and $0.5 \mathrm{U}$ Kapa Taq DNA polymerase (Kapa Biosystems, Boston, MA, USA). Amplification was performed with a touch-down cycling process. Each set of 96 reactions included a positive control and a blind sample (without DNA). The PCR products were resolved on $8 \%$ denaturing polyacrylamide gels (Sambrook and Russell, 2001). The multilocus AFLP profiles were scored as present (1), absent (0) or ambiguous (?) to create binary matrices using MyImageAnalysis Software (Thermo Scientific, Rockford, IL, USA). Two samples were included in all polyacrylamide gels to ensure comparability among gels. Furthermore, 36 samples were twice amplified and run in polyacrylamide gels to calculate the error rate of the AFLP analysis (Bonin et al., 2004), considering the ratio between observed and total number of phenotypic differences between replicates.

\section{Genetic Diversity Analysis}

A binary matrix of 1 and 0 values was generated based on the presence (1) or absence (0) of AFLP fragments in every sample for each selected pair of primers. The AFLP fragment presence/absence matrix was used to calculate descriptive statistics indices, including number of alleles, allele frequencies and percentage of polymorphic loci at the 5\% level based on the Lynch and Milligan method implemented in AFLP SURV software version 1.0 (Vekemans et al., 2002). The numbers of private alleles and fixed alleles were calculated with FAMD (Schlueter and Harris, 2006). Estimates of expected heterozygosity $(\mathrm{Hj})$, mean gene diversity $(\mathrm{Hw})$ within populations (analogous to Nei's gene diversity within populations $\mathrm{Hs}$ ), total gene diversity $(\mathrm{Ht})$, and differentiation among populations $\left(F_{\mathrm{ST}}\right)$ in Antarctica and South Patagonia were analyzed using fragment frequency data, by comparing the levels of polymorphism. The genetic differentiation considered three hierarchical levels; genetic differentiation among populations, among islands and among regions (southern Patagonia and Antarctica). Given that samples were gametophytes [i.e., haploid $(n)$ individuals], we followed the recommendation of the author for computing fragment frequency which reserves one option for haploid organisms and fixed homozygosity at each locus because of complete self-fertilization (Vekemans et al., 2002). The significance of the genetic differentiation among populations was 


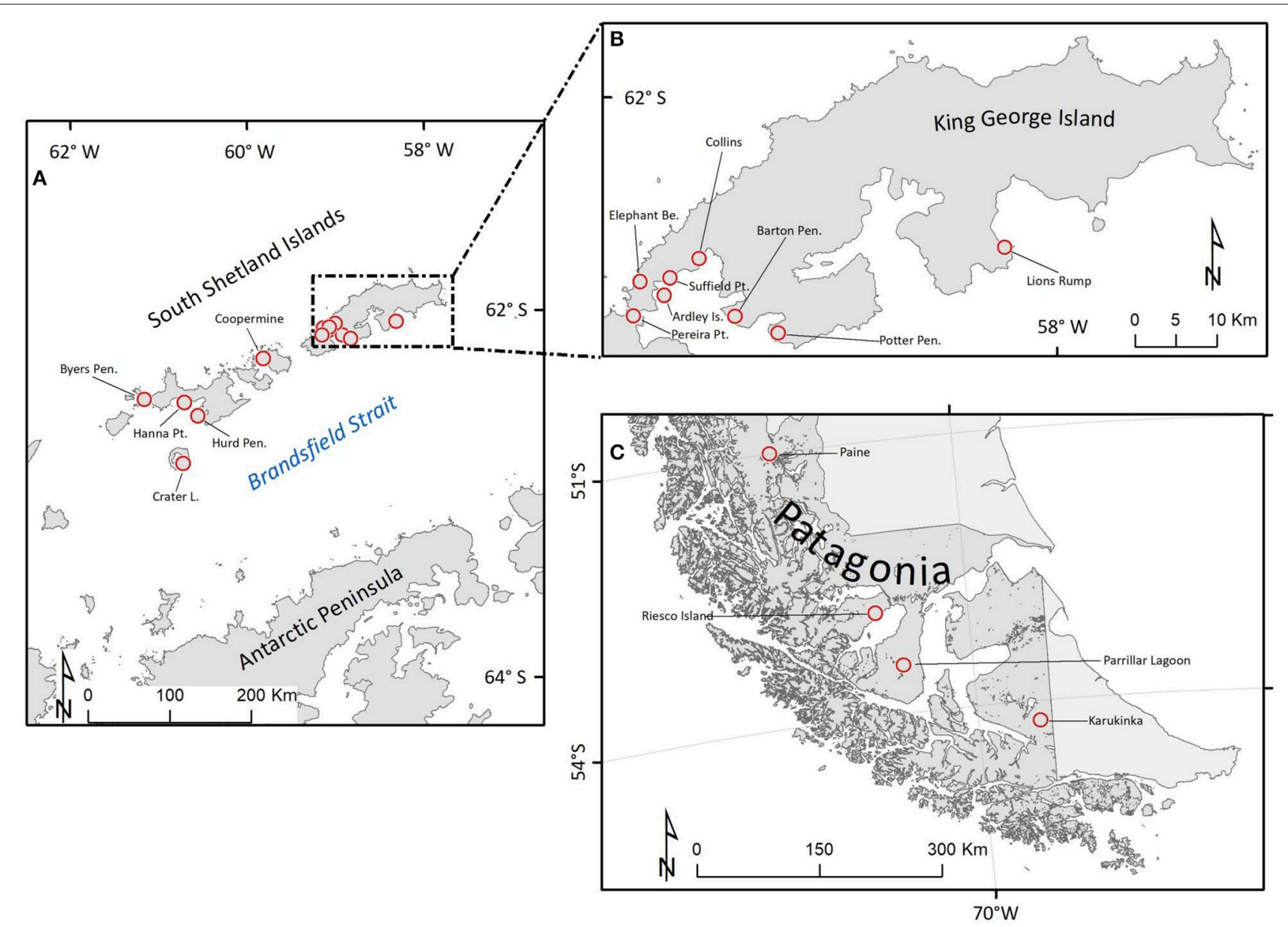

FIGURE 1 | Sampling locations of Sanionia uncinata populations in Maritime Antarctica and southern Patagonia (Chile). (A) Populations belonging to the South Shetland Islands: Byers Peninsula, Hurd Peninsula, and Hanna Point on Livingston Island (LI); Crater Lake on Decepcion Island (DI); Coppermine Peninsula on Robert Island (RI). (B) Inset detail for Pereira Point on Nelson Island (NI) and for populations on King George Island (KGI): Ardley Island, Elephant Beach, Suffield Point, Collins, Barton Peninsula, Potter Peninsula, and Lions Rump; (C) Populations along a latitudinal gradient in Southern Patagonia: Paine, Riesco, Parrillar Lagoon, and Karukinka (Chile).

tested under the hypothesis of no genetic structure, obtained by 10,000 random permutations of individuals among populations using AFLP-SURV 1.0 software (Vekemans et al., 2002).

A model-based clustering method implemented in the program STRUCTURE version 2.3.4 (Pritchard et al., 2000) was used first under a non-admixture model, as suggested by the authors for dominant markers, to infer population structure without considering sampling locations or allele frequencies correlated within populations. The burn-in was set to 10,000 and Markov chain Monte Carlo (MCMC) was set to 50.000, simulating number of clusters from $\mathrm{K}=1$ to $\mathrm{K}=17$ and 100 iteration for each cluster. We calculated $\Delta K$, suggested by Evanno et al. (2005), which detects the true $\mathrm{K}$ as the maximum value of ' $\mathrm{Ln} P(\mathrm{D})$ implemented in Structure Harvester (Earl and Vonholdt, 2012) to assign individuals to the clusters probabilistically. We used the admixture model using prior population information with burn-in rate of 500,000 and MCMC of $10^{6}$ runs simulating cluster numbers from 1 to 5 . Under the admixture model, STRUCTURE was used to identify individuals in each population that formed subpopulations or that had recent immigrant ancestry. Then the samples were grouped according to the probability of belonging to the subpopulations recorded by STRUCTURE and checked the level of polymorphic alleles and the level of expected heterozygosity based on the Lynch and Milligan method within subpopulations. To detect if the apparent reduction of heterozygosity in a population is caused by a subpopulation structure, we compared the level of expected heterozygosity under Hardy-Weinberg genotypic proportions for each populations.

To test for isolation by distance, pairwise genetic and spatial distances were correlated using the Mantel test (Mantel, 1967). Also, genetic differentiation of population pairs was estimated with $\Phi_{\mathrm{PT}}$ (a statistic analogous to $F_{\mathrm{ST}}$ ) for AFLPs with their significance level (obtained by 9999 permutations). A principal coordinate analysis (PCoA) was performed to observe the distribution and ordering of the individuals on a 
multidimensional axis system. The principal coordinates were calculated from pairwise Euclidian distance estimates between individual genotypes. Analyses were performed in GenAlEx6.5 (Peakall and Smouse, 2006, 2012).

The clustering analysis calculated a population distance matrix from the allele frequency data of all defined groups using the default option (Bayesian from a non-uniform amongpopulations prior) implemented in FAMD software (Schlueter and Harris, 2006). The bootstrap population tree option was used to generate multiple UPGMA or NJ trees from a distance matrix or Jaccard similarity index. Statistical support for the branches was assessed by 10,000 bootstrap replicates. The dendrogram was viewed using Treeview X 1.6.6 software (Page, 1996).

\section{RESULTS}

\section{Genetic Diversity Within and Among Populations}

In total, 142 alleles were scored in the 281 studied samples. The average proportion of polymorphic alleles was $12.9 \%$. The mean scoring error calculated from 36 duplicate samples was $2.47 \%$. The largest proportion of polymorphic loci was on the Shetland Islands population at Coppermine (RI) $(60.6 \%)$ followed by the populations at Byers (LI) (47.2\%) and Suffield (KGI) (38\%) (Table 1). The lowest $H j$ value was found in the Lions Rump, Hurd, Deception and Paine populations and the highest value was in the Coppermine population (0.20). The mean gene diversity within populations of $S$. uncinata was $H w$ : 0.04 . Total gene diversity $(\mathrm{Ht})$ was 0.0550 and genetic differentiation among populations was not significant $\left(F_{\mathrm{ST}}=0.2426, P=0.1867\right)$. We found private alleles in only one population (Karukinka). The Mantel test indicated that genetic variability was not correlated with geographic distance $\left(\mathrm{R}^{2}=0.031\right)$. The AMOVA analysis indicated that $41 \%$ of genetic variability was within populations and $59 \%$ was among populations $\left(\Phi_{\mathrm{PT}}=0.592\right)$.

The PCoA found three main groups (Figure 2). The distribution of the samples of group 1, formed by populations of Coppermine, Parrillar, Suffield, Karukinka, Collins, Byers, and Lions Rump was homogeneous, as was the distribution of group 2 , formed by the populations Barton, Riesco, Paine, Pereira, and Elephant. In contrast, group 3 was not homogeneous, because it mixed samples from group 1 and 2 with the remaining samples of the Potter, Hanna, Hurd, Ardley, Deception populations.

The first principal coordinate explained $47.10 \%$ of the total variability, and the second and third axes explained much smaller proportions of total variability (12.35 and 7.10\%, respectively). Thus $59.45 \%$ of the variability was visualized by the bidimensional coordinates system.

In accordance with the results of the Mantel test, which inferred absence of geographic relationships among the studied populations, the populations cluster in the dendrogram partially accordingly to their geographic position (Figure 3). For example, populations situated along the west-east orientation in King George Island, Elephant Bay and Barton populations clustered together. However, they did not cluster with nearer populations such as Suffield, Collins, or Ardley in KGI. Elephant Bay and Barton clustered with the Riesco population in southern Patagonia. We note clustering in Livingston Island for Hanna Point and Hurd, but the Byers population was in another branch.

Coppermine, Suffield, Byers from the maritime Antarctica and Parrillar from Southern-Patagonia shared the same lineage and diverged from the rest of the populations.

\section{Genetic Analysis Among Islands}

Robert Island had the highest number of polymorphic loci (60.6\%) and the highest expected heterozygosity per island (0.20), followed by Livingston Island (47.2\%), and southern Patagonia (21.1\%). The lowest levels of polymorphism were found in King George Island (6.3\%), Nelson Island (2.8\%), Ardley Peninsula (0\%), and Deception Island (0\%). The $H w$ was 0.05 and $\mathrm{Ht}$ was 0.0648 . The genetic differentiation among islands $\left(F_{\mathrm{ST}}=\right.$ 0.11 ,) was not significant. The AMOVA analysis indicated that $58 \%$ of the genetic variability was within populations and $42 \%$ was among island $\left(\Phi_{\mathrm{PT}}=0.42\right)$. The Mantel test indicated that genetic variability was not correlated with geographic distance $\left(\mathrm{R}^{2}=0.0006\right)$.

\section{STRUCTURE Analysis}

Bayesian analysis with STRUCTURE showed that samples are best grouped into two clusters with both the non-admixture model and admixture models. The highest value was found for $\Delta \mathrm{K}=2$ (Cluster 1 and Cluster 2). Each cluster includes populations from maritime Antarctica and southern Patagonia (Figure 4). We detected lower gene diversity for subpopulations of cluster 1, and higher gene diversity for subpopulations belonging to cluster 2 . The mean within-population expected heterozygosity under Hardy-Weinberg genotypic proportions (Nei's gene diversity) within clusters of S. uncinata was higher in comparison with the same analysis considering each population ( $H w: 0.10)$. The analyses of genetic structure among clusters showed that the $\mathrm{Ht}$ was 0.1129 and that there was a significant genetic differentiation among them $\left(F_{\mathrm{ST}}=0.06,{ }^{* * *} P<0.001\right)$.

\section{Analysis Under Admixture Model}

The STRUCTURE analysis allowed us to identify subpopulations under the admixture model. Due to the clearly geographically limited subpopulations of $S$. uncinata in some populations, we decided to analyze the level of polymorphic alleles and the level of gene diversity within subpopulations to compare it with the previous analysis to know if the subpopulation have some influence in the final interpretation of the results. We did the analysis by grouping the samples in the subpopulations registered by STRUCTURE, symbolized by A for samples belonging to cluster 1 and B for samples belonging to cluster 2 .

This new genetic analysis showed that the average proportion of polymorphic alleles was $16.4 \%$. The largest proportion of polymorphic loci was found in Coppermine B (RI) and Suffield Point B (KGI) (each 65.5\%) followed by Byers B (LI) (60.5). It was revealed that some differences in the level of polymorphic loci exist compared to the previous analysis that we have done without grouping the samples according to STRUCTURE. For example, individuals from Coppermine Peninsula (RI), grouped into two subpopulations. The analysis revealed a high level of 


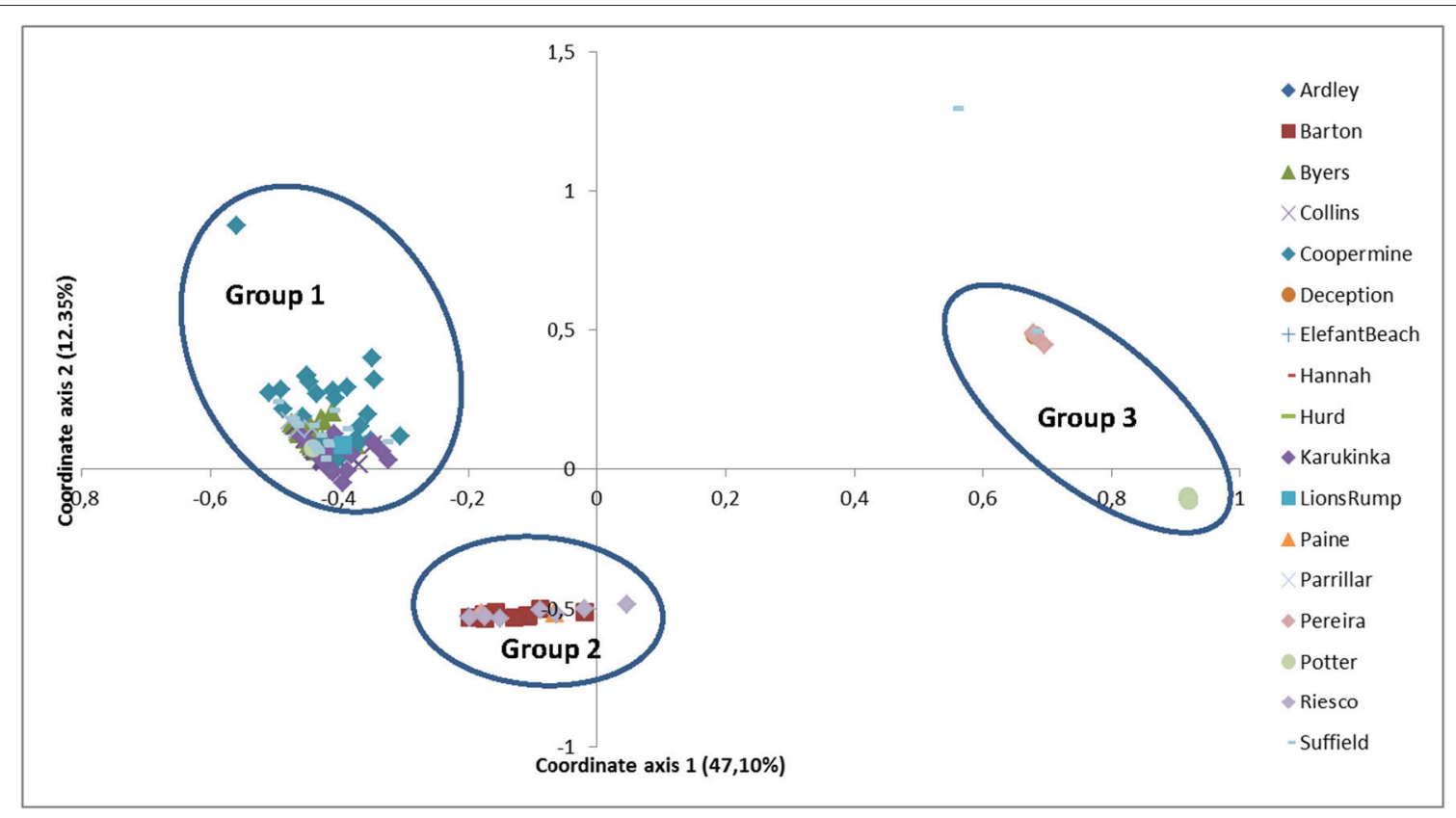

FIGURE 2 | Results of the principal coordinate analysis for 17 populations of Sanionia uncinata. The first principal coordinate explained $47.10 \%$ of the total variability and the second coordinate explained $12.35 \%$.

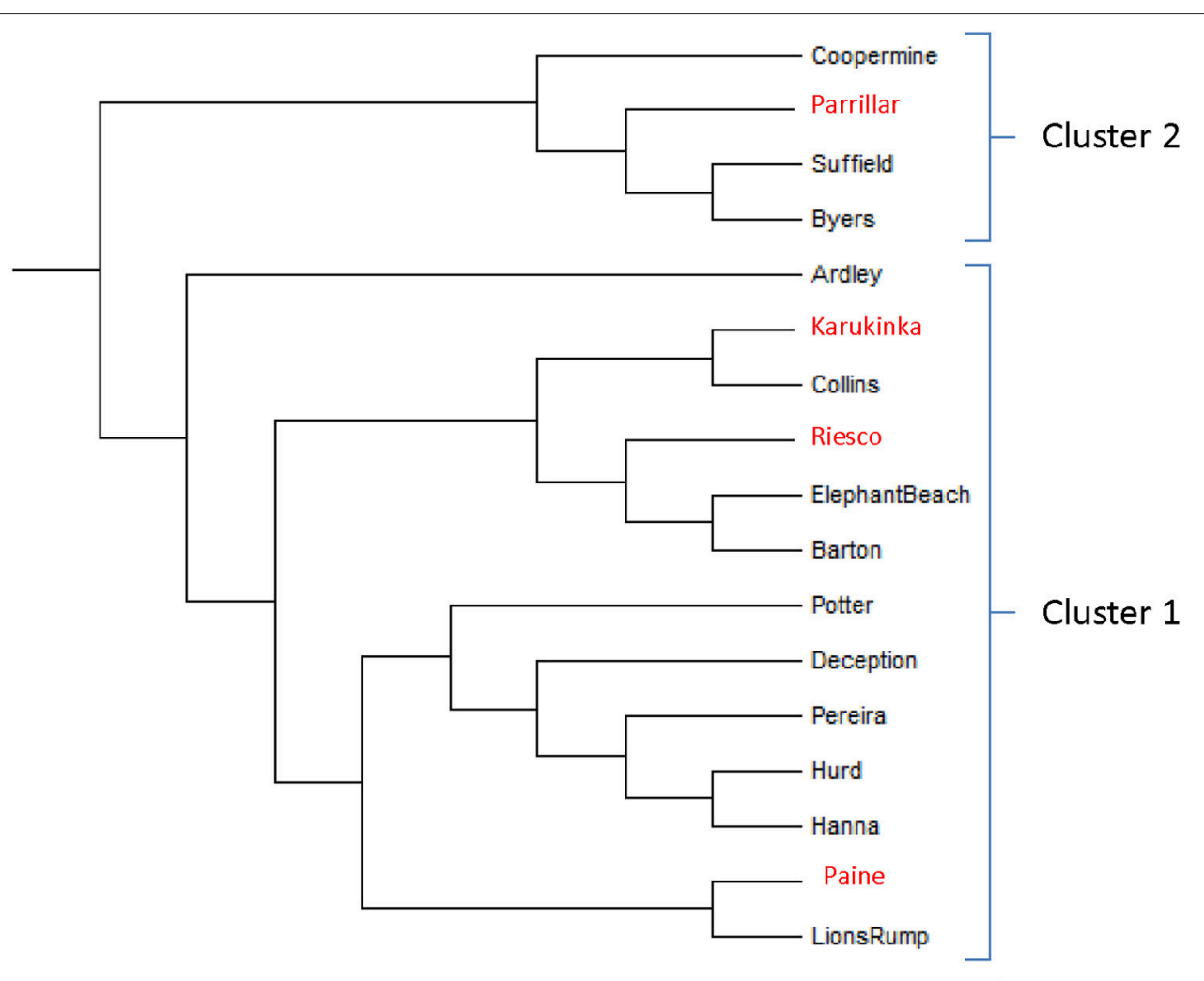

FIGURE 3 | Neighbor-joining tree showing clustering among studied Sanionia uncinata populations from Antarctica and southern Patagonia. Clusters 1 and 2 are the same groups of populations defined by the software STRUCTURE. Populations from southern Patagonia are red marked. 


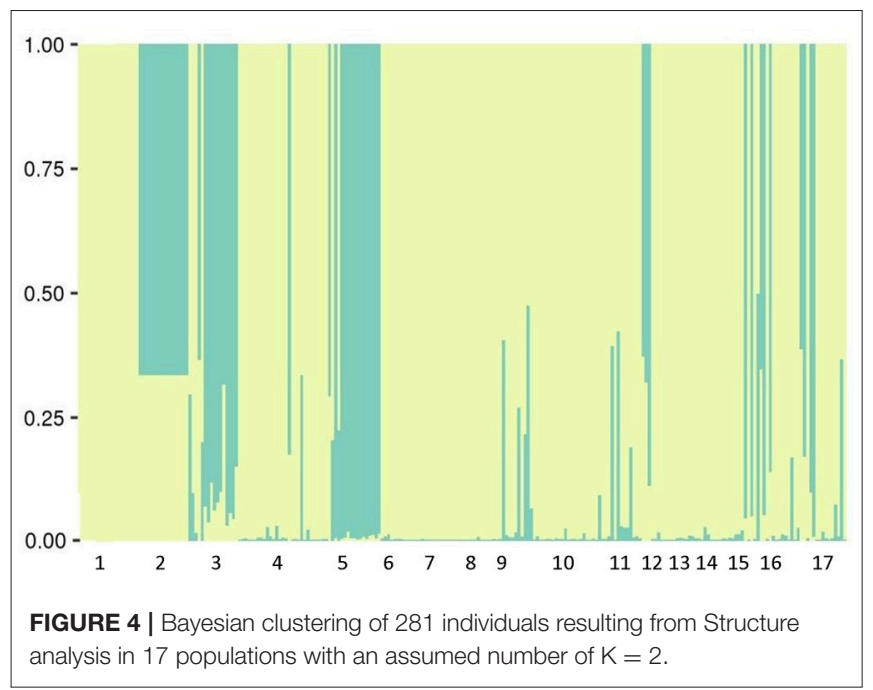

polymorphism for Coppermine B shown with the blue line and a lower level in the samples shown with the red line, Coppermine A. (Table 2 and Figure 5).

Other geographically delimited subpopulations were observed in Byers Peninsula (LI) (Figure 6) and Suffield Point (KGI) (Figure 7). All samples from Barton Peninsula (KGI) revealed a mixed ancestry. Isolated samples were found to have mixed ancestry or to belong totally to cluster 2 in populations such as Collins (KGI) and Karukinka in southern Patagonia.

The mean within-population expected heterozygosity under Hardy-Weinberg genotypic proportions (Nei's gene diversity) within populations of $S$. uncinata was similar to that calculated in the first analysis (Hw: 0.055). The highest scores of expected heterozygosity $(\mathrm{Hj})$ were observed in Coppermine B (0.25), Byers B (0.187), and Suffield B (0.185) subpopulations in maritime Antarctica and Parrillar Lagoon (0.11) in Southern Patagonia (Table 2).

The analyses of population genetic structure found $\mathrm{Ht}=0.072$ and a significant genetic differentiation among (sub)populations $\left(F_{\mathrm{ST}}=0.237,{ }^{*} \mathrm{P}<0.05\right)$.

\section{DISCUSSION}

Compared to other studied moss species, our populations of $S$. uncinata have shown similar or lower mean values for withinpopulation gene diversity at populations and islands levels. Van Der Velde and Bijlsma (2000) reported low levels of microsatellite variability with gene diversity $\mathrm{Hs}$ ranging from 0,243 to 0,281 along with high genotypic diversity concluding that sexual reproduction in their studied populations of Polytrichum formosum had to have a stronger influence on the genetic structure of the species than clonal reproduction. In a study of the widespread Mediterranean moss Pleurochaete squarrosa (Grundmann et al., 2007) also described low within-population values of gene diversity with a mean value over thirty populations of Hs of 0,034 for nuclear DNA ITS markers. These authors found high levels of linkage among loci and explained their
TABLE 2 | Results of genetic diversity analyses in each population and subpopulation.

\begin{tabular}{|c|c|c|c|}
\hline Population & $n$ & $\%$ PLP & $\mathrm{Hj}$ \\
\hline Ardley & 24 & 0.0 & 0.00033 \\
\hline Barton & 16 & 11.2 & 0.02874 \\
\hline Byers_A & 12 & 19.0 & 0.03242 \\
\hline Byers_B & 12 & 60.6 & 0.18797 \\
\hline Collins_A & 19 & 16.9 & 0.02267 \\
\hline Collins_B & 2 & 14.1 & 0.10563 \\
\hline Coppermine_A & 10 & 14.1 & 0.04351 \\
\hline Coppermine_B & 14 & 65.5 & 0.25186 \\
\hline Deception & 10 & 0.0 & 0.00000 \\
\hline Elephant Beach & 17 & 1.5 & 0.00175 \\
\hline Hannah & 12 & 0.8 & 0.00237 \\
\hline Hurd & 11 & 0.0 & 0.00000 \\
\hline Karukinka_A & 26 & 14.8 & 0.03645 \\
\hline Karukinka_B & 4 & 26.8 & 0.09950 \\
\hline LionsRump & 10 & 0.0 & 0.00000 \\
\hline Paine & 11 & 0.0 & 0.00000 \\
\hline Parrillar & 9 & 19.0 & 0.11268 \\
\hline Pereira & 11 & 2.8 & 0.00661 \\
\hline Potter & 11 & 9.9 & 0.01778 \\
\hline Riesco & 10 & 13.4 & 0.05152 \\
\hline Suffield_A & 20 & 6.3 & 0.02362 \\
\hline Suffield_B & 10 & 65.5 & 0.18564 \\
\hline
\end{tabular}

\%PLP, proportion of polymorphic loci at $5 \%$ level; $\mathrm{Hj}$, expected heterozygosity under $\mathrm{H}-\mathrm{W}$ proportion.

results with the model of Kimmerer (1991) who suggested that extensive vegetative propagation was responsible in her study for population growth, while the function of spores was to establish new populations.

We could distinguish two groups of populations. One of them clustered populations with either non-polymorphism or with low to very low values of genetic diversity. The other one was made out of populations showing much higher genetic diversity. We found that cluster 1, with lower levels of polymorphism and a low average of expected heterozygosity (0.03), was the most widely distributed, including populations from the northern part of southern Patagonia to the southern part of maritime Antarctica. Regarding cluster 2, it was formed by populations with the highest level of polymorphism and heterozygosity $(0.17)$ restricted to 4 studied populations on the maritime Antarctica and Southern-Patagonia such as Parrillar Lagoon in SouthernPatagonia, Coppermine Peninsula (RI), Suffield (KGI), and Byers Peninsula (LI) in maritime Antarctica.

This dichotomy may also be partly explained by the model of Kimmerer. Vegetative propagation could be happening in some populations through gametophyte settlement with diaspores advancing with predominant western winds in the Southern Hemisphere (Muñoz et al., 2004), or being transported by birds (Parnikoza et al., 2018) or carried by snow and streams (McDaniel and Miller, 2000), while sexual reproduction could occur in Antarctica under appropriate environmental conditions 


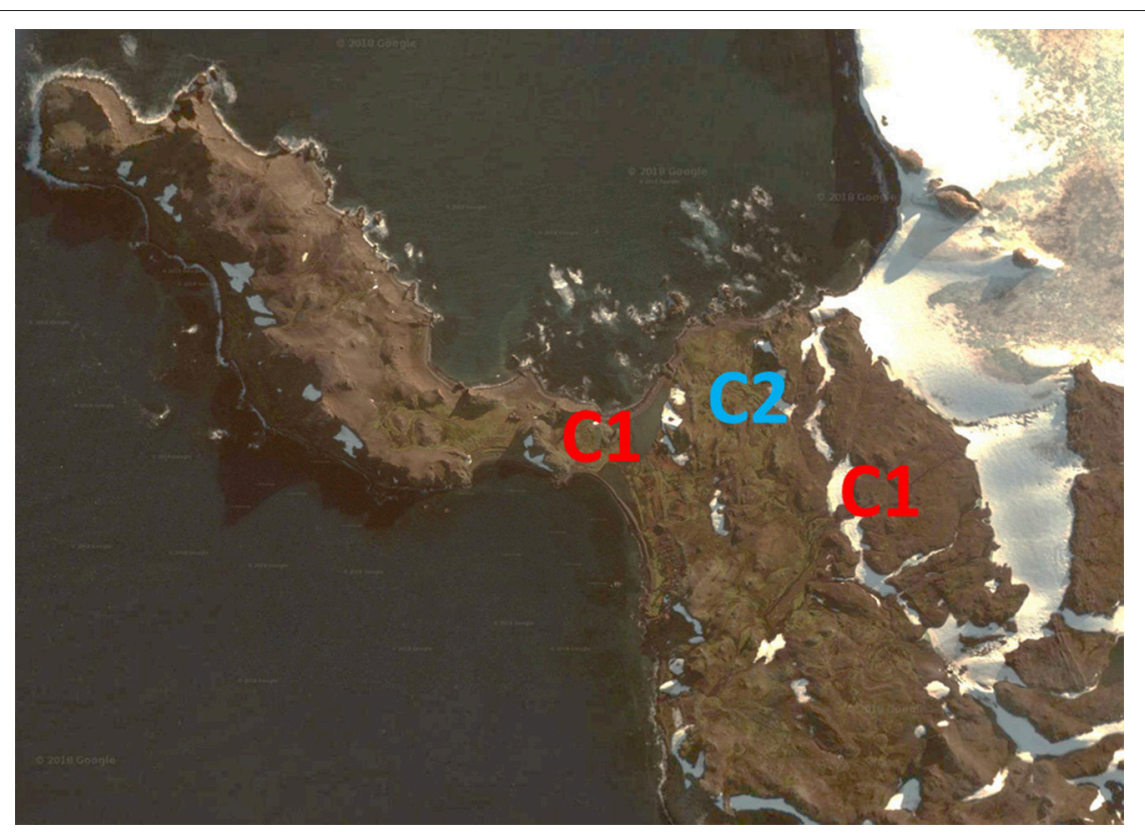

FIGURE 5 | Samples of Coppermine Peninsula (RI) populations grouped into two subpopulations. C1 indicate samples assigned to cluster 1 (Coppermine A). C2 group individuals assigned to cluster 2 (Coppermine B). Image capture from GoogleEarth.

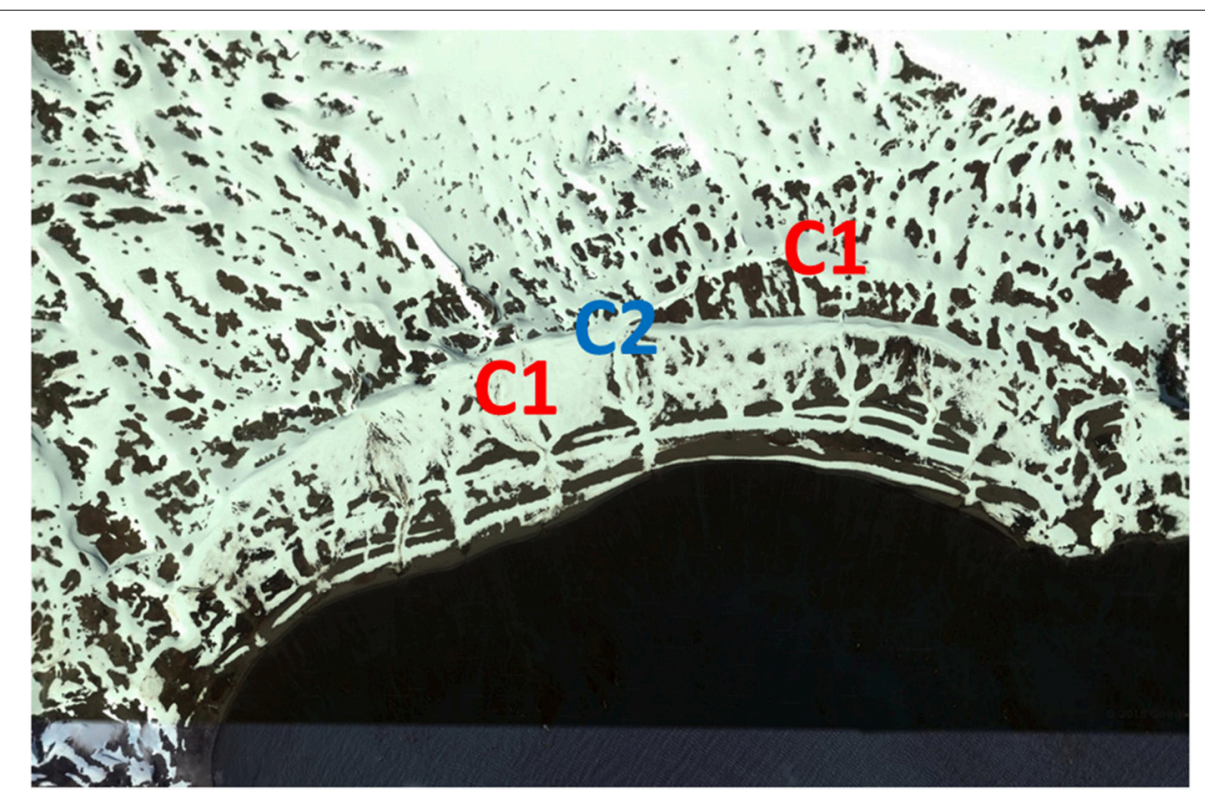

FIGURE 6 | Samples of Byers Peninsula (LI) population grouped into two subpopulations. C1 indicate samples assigned to cluster 1 which conform the population Byers A. C2 groups individuals assigned to cluster 2 conformed by Byers B. Image capture from GoogleEarth.

such as temperature and elevation conditions- which are the most significant abiotic factor affecting the presence of this moss species (Gonzalez et al., 2013). Microclimatic differences may explain why populations in the same area do not show the same levels of genetic diversity, although they are also under the influence of western winds. Ground surface temperatures have an important influence on biota biology, composition and distribution, such as in the case of the South Orkney IslandSouth Shetland Islands and south to Marguerite Bay (Smith and Convey, 2002), the Walker Glacier in Alaska (Dickson and Johnson, 2014), and in wind-protected sites with higher soil temperatures in the frontal moraine of the Bellingshausen glacial dome located north of Fildes Peninsula (Hebel et al., 2012). Convey et al. (2018) have shown that for Antarctic regions 


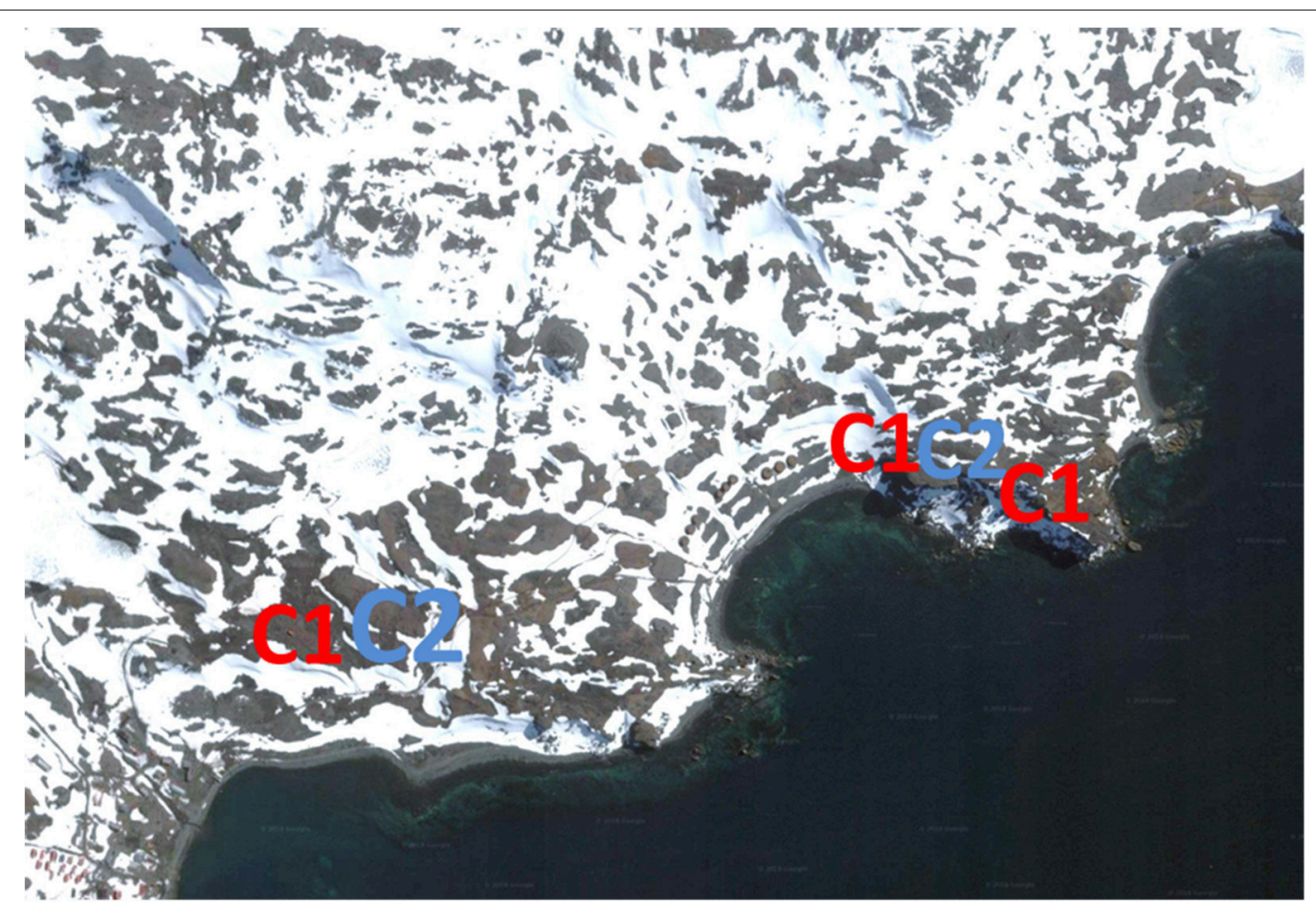

FIGURE 7 | Samples of Suffield Point population and surroundings areas (KGI). C1 indicate samples assigned to cluster 1, Suffield A. C2 group individuals assigned to cluster 2, Suffield B. Image capture from GoogleEarth.

"thermal environment is site-specific and can differ greatly over a landscape scale." In our case, unfavorable ground temperatures at some places could be preventing wind dispersed spores to establish counteracting the potential positive effects of wind on gene dispersal. Moreover, unfavorable ground temperatures could hinder the production of sporophytes leading also to reduced gene diversity and population substructuring. In this case, asexual reproduction could take the leading role in maintaining the populations as has been shown for other moss species growing under harsh environments (Frey and Kurschner, 2011).

But the low level of gene diversity could be also linked to the autoecious condition of $S$. uncinata since the level of heterozygosity depends both on the potential of self-crossing and on the haploid or diploid condition of an organism (McDaniel and Miller, 2000; Eppley et al., 2007). As a result, the frequent presence of gametophytes [i.e., haploid $(n)$ individuals] of $S$. uncinata in Antarctica could bring the population to complete homozygosis in one generation. Another reason for low values of genetic diversity could be seen after a genetic drift in the influence of colonization events at the distribution edges and events of adaptation (Daniels et al., 2018). This may be of special importance on those areas where ice is retreating. Our results did not provide enough information to distinguish among all these different factors.

As suggested by Hedenas (2012) and supported also by other independent evidence like pollen rain studies (Marshall and Convey, 1997; Hebel and Rojas, 1999), it seems possible that the levels of gene flow during post-glacial colonization were sufficient to prevent a higher level of genetic differentiation among the studied populations. The applied Mantel test did not find correlation between genetic variability and geographic distance. This is also confirmed by the phylogenetic tree, which did not reveal geographically limited areas linked to genetic similarities.

Differentiation among populations becomes significant with the analysis of the substructure of populations for the Coppermine, Suffield and Byers populations (Figures 5-7) where the underlying causes of this subdivision could be the monoecious condition of the species, the typical asexual state, the low formation of sporophyte, and geographical or ecological barriers (isolation) to gene flow. However, it could be also possible that the high level of gene diversity in these three populations represents a new and recent colonization event after the ice retreat, because otherwise it is expected that autoecious species having mostly haploids states show lower levels of genetic diversity in each generation, which is not evident in our results.

Karukinka was the only site that had private alleles, indicating they have been genetically isolated for some time. On the other hand, it could be the origin of most of the samples in Antarctica linked to cluster 1, consistent with the dispersal via the western winds predominant from southern South America to Antarctica, and may have been acting as a refuge during the LGM, as described for Buellia frigida (Jones et al., 2015). However, our results indicated that gene flow is not limited to the route from South America to Antarctica, and evidently it 
could also travel from Antarctica to southern Patagonia. Thus some samples in southern Patagonia have shown their ancestral origin in Antarctic populations. For example, in Karukinka four samples belong to cluster 2, which could be explained by gene flow from Antarctica to southern Patagonia (Table 1). The same relation was observed in Parrillar Lagoon in southern Patagonia, where most of the samples trace their ancestry to the Coppermine or Byers populations. This means that even with a low level of sporophyte development, the level of gene flow does not imply geographic restriction to gene flow and has occurred among Antarctica and southern Patagonia. This fact could increase the genetic diversity of the species within Antarctica and from Antarctica to other parts. The backward air trajectories detected using the HYSPLIT (HYbrid Single-Particle Lagrangian Integrated Trajectory) model (Stein et al., 2015) depict the transport of air masses in both directions between Patagonia and the SSI (Figure 8). This suggests that either spores or gametophytes have been responsible for migration within Antarctica, and from Antarctica to South America and vice versa. The dispersal model was not linked to predominant winds and fluctuated during the year and among years. The frequency of dispersal from Antarctica to South America is unpredictable, but based on the frequency of individuals that trace their ancestry to southern Patagonia, dispersal from Antarctica to Southern-Patagonia has been less frequent than in the opposite direction.

Present landscapes found in southern Patagonia and Antarctica offer a unique habitat for plant species establishment due to their particular environmental characteristics. In particular, they can provide new ground areas for moss colonization where the ice retreats. In some areas it is even possible that sediments and rocks are deposited on the glacier by the wind or through shearing from peripheral areas, also resulting in new areas for moss colonization. Furthermore, moss spore banks can act as accumulative genetic variation and colonize temporary microsites such as moraines as well as in high areas where the snow melts more quickly.

Consistent with the results of Hedenas (2012), our results suggest that the distribution of Sanionia in Antarctica and southern Patagonia is not linked to spatially limited refuges. The importance of geothermal sites as a refugium for genetic diversity has been highlighted in Fraser et al. (2014). Contrastingly, allele diversity on Deception Island was fixed although it is a geothermal site. One possible explanation for the lack of genetic diversity could be the highly active and recent volcanic dynamism since the nineteenth century on the island (Geyer et al., 2017).

All these places can be of special interest for researchers working on succession events who need to study variables such as exposure, height, roughness, and other factors related to substrate that could provide advantages for new settlers. Linked to molecular analyses the genetic diversity within species, helps to attribute if these characteristics are caused by natural processes associated with climatic or tectonic events, environmental variables at present or in the past or anthropogenic activities. This information allows us to identify links between species' colonization and glacial refuges and/or routes of dispersion.

The results of our genetic analyses, suggest that there is a gene flow route not only in the direction from South America to Antarctica but also from Antarctica to South America and within Antarctica. This means that our results support the concept of genetic connectivity among bioregions located on terrestrial areas of southern Patagonia and Antarctica and this interaction
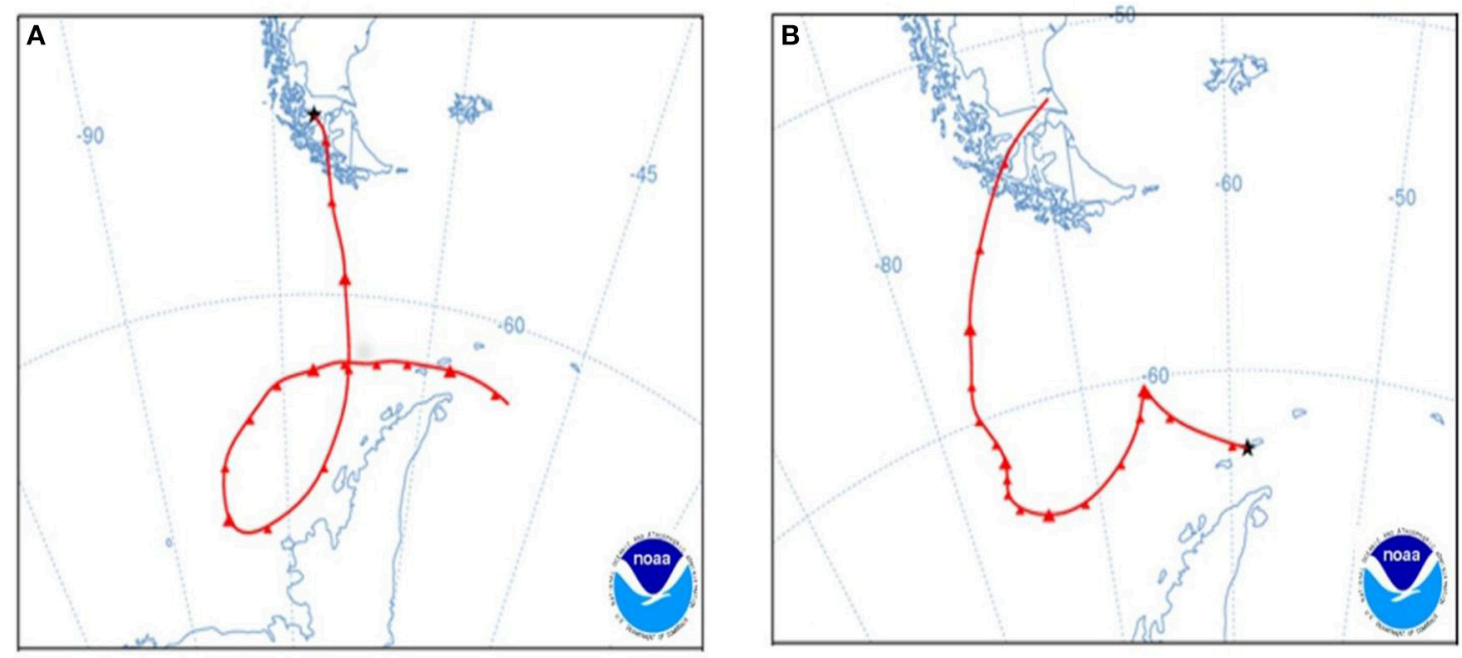

FIGURE 8 | Air mass transportation supported by forward a trajectory model using NOAA HYSPLIT (HYbrid Single-Particle Lagrangian Integrated Trajectory) (Stein et al., 2015; Rolph et al., 2017). (A). Air masses moving southwards and passing over South Shetland Islands after $96 \mathrm{~h}$ of transport starting from a source location at Riesco Island (52.78 S, $71.70^{\circ} \mathrm{W}, 100 \mathrm{~m}$ above ground level) in Chilean Patagonia. Trajectory initiated at 08:00 UTC on 29 October 2006, using archived meteorological data from Global Data Assimilation System (GDAS) [NOAA HYSPLIT Job ID:187887]. (B) Air masses moving northwards after 108 h of transport starting from a source location at Barton Peninsula ( $62.23^{\circ} \mathrm{S}, 58.76^{\circ} \mathrm{W}, 100 \mathrm{~m}$ above ground level) on King George Island, South Shetland Islands. Trajectory initiated at 05:00 UTC on 02 February 2007, using archived meteorological data from NCEP/NCAR Global Reanalysis [NOAA HYSPLIT Job ID:187267]. 
may have occurred repeatedly after the LGM, resulting in the vegetation that grows in Antarctica today.

Considering the consequences of inbreeding depression in mosses (Eppley et al., 2007) and that our species is autoecious found mostly in haploid state, the recognition of geographically well-defined subpopulations with high levels of polymorphism would be important in studies applied to climate change, resilience and conservation of the species in Antarctica because the relatively recent colonization which should be a relevant target zone to manage.

\section{DATA AVAILABILITY STATEMENT}

- Datasets are available on request:

The raw data supporting the conclusions of this manuscript will be made available by the authors, without undue reservation, to any qualified researcher.

\section{AUTHOR CONTRIBUTIONS}

IH conceived the ideas, designed study, performed research, analyzed data, led the writing. MD and JB performed research.

\section{REFERENCES}

Bijlsma, R., van der Velde, M., van de Zande, L., Boerema, A. C., and van Zanten, B. O. (2000). Molecular markers reveal cryptic species within Polytrichum commune (common hair-cap moss). Plant Biol. 2, 408-414. doi: $10.1055 / \mathrm{s}-2000-5952$

Birkenmajer, K., Ochyra, R., Olsson, I. U., and Stuchlik, L. (1985). Midholocene radiocarbon-dated peat at Admiralty Bay, King-George-Island (South-Shetland-Islands, West Antarctica). Bull. Polish Acad. Sci. Earth Sci. 33, $7-13$.

Bonin, A., Bellemain, E., Eidesen, P. B., Pompanon, F., Brochmann, C., and Taberlet, P. (2004). How to track and assess genotyping errors in population genetics studies. Mole. Ecol. 13, 3261-3273. doi: 10.1111/j.1365-294X.2004.02346.x

Caners, R. T., Ellen Macdonald, S., and Belland, R. J. (2009). Recolonization potential of bryophyte diaspore banks in harvested boreal mixed-wood forest. Plant Ecol. 204, 55-68. doi: 10.1007/s11258-008-9565-0

Clarke, L. J., Ayre, D. J., and Robinson, S. A. (2009). Genetic structure of East Antarctic populations of the moss Ceratodon purpureus. Antarct. Sci. 21, 51-58. doi: 10.1017/S0954102008001466

Convey, P., Coulson, S. J., Worland, M. R., and Sjoblom, A. (2018). The importance of understanding annual and shorter-term temperature patterns and variation in the surface levels of polar soils for terrestrial biota. Polar Biol. 41, 1587-1605. doi: 10.1007/s00300-018-2299-0

Dale, T. M., Skotnicki, M. L., Adam, K. D., and Selkirk, P. M. (1999). Genetic diversity in the moss Hennediella heimii in Miers Valley, southern Victoria Land, Antarctica. Polar Biol. 21, 228-233. doi: 10.1007/s003000050357

Daniels, R. R., Taylor, R. S., Serra-Varela, M. J., Vendramin, G. G., GonzalezMartinez, S. C., and Grivet, D. (2018). Inferring selection in instances of longrange colonization: the Aleppo pine (Pinus halepensis) in the Mediterranean Basin. Mole. Ecol. 27, 3331-3345. doi: 10.1111/mec.14786

Dickson, J. H., and Johnson, R. E. (2014). Mosses and the beginnings of plant succession on Walker Glacier, southeastern Alaska. Lindbergia 37, 60-65. doi: 10.25227/linbg.01052

Earl, D. A., and Vonholdt, B. M. (2012). Structure Harvester: a website and program for visualizing Structure output and implementing the Evanno method. Conserv. Genet. Res. 4, 359-361. doi: 10.1007/s12686-011-9548-7
RJ performed research, analyzed data. All authors discussed the results and jointly worked on the manuscript.

\section{FUNDING}

Project T_17-09 (INACH). Project ACT-105, CONICYTPrograma de Investigación Asociativa, PIA (Anillos Antárticos). Project BMBF-Conicyt Responses of Glaciers, Biosphere and Hydrology to climate variability across the Southern Andes (GABY-VASA). Programa de Mejoramiento Institucional PMI MAG 1203 Gaia-Antártica.

\section{ACKNOWLEDGMENTS}

We thank the Chilean Antarctic Institute (INACH) for supporting this work. We thank the Wildlife Conservation Society to support our sampling and research in Karukinka. The authors gratefully acknowledge the NOAA Air Resources Laboratory (ARL) for the provision of the HYSPLIT transport and dispersion model and/or READY website (http://www.ready. noaa.gov) used in this publication. We also thank the anonymous referees for their comments.

Ellis, L. T., Asthana, A. K., Gupta, R., Nath, V., Sahu, V., Bednarek-Ochyra, H., et al. (2013a). New national and regional bryophyte records, 34. J. Bryol. 35, 62-70. doi: 10.1179/1743282012Y.0000000042

Ellis, L. T., Bednarek-Ochyra, H., Ochyra, R., Benjumea, M. J., Sais, L. V., Caparros, R., et al. (2013b). New national and regional bryophyte records, 35. J. Bryol. 35, 129-139. doi: 10.1179/1743282013Y.0000000049

Eppley, S. M., Taylor, P. T., and Jesson, L. K. (2007). Self-fertilization in mosses: a comparison of heterozygote deficiency between species with combined versus separate sexes. Heredity 98, 38-44. doi: 10.1038/sj.hdy.6800900

Evanno, G., Regnaut, S., and Goudet, J. (2005). Detecting the number of clusters of individuals using the software structure: a simulation study. Mole. Ecol. 14, 2611-2620. doi: 10.1111/j.1365-294X.2005.02553.x

Fildani, A., Romans, B. W., Fosdick, J. C., Crane, W. H., and Hubbard, S. M. (2008). "Orogenesis of the Patagonian Andes as reflected by basin evolution in southernmost South America," in Ores and Orogenesis: Circum-Pacific Tectonics, Geologic Evolution, and Ore Deposits, Vol. 22, eds J. E. Spencer and S. R. Titley (Tucson, AZ: Arizona Geological Society Digest), 259-268.

Fraser, C. I., Terauds, A., Smellie, J., Convey, P., and Chown, S. L. (2014). Geothermal activity helps life survive glacial cycles. Proc. Nat. Acad. Sci. U.S.A. 111, 5634-5639. doi: 10.1073/pnas.1321437111

Frey, W., and Kurschner, H. (2011). Asexual reproduction, habitat colonization and habitat maintenance in bryophytes. Flora 206, 173-184. doi: 10.1016/j.flora.2010.04.020

Geyer, A., Marti, A., Giralt, S., and Folch, A. (2017). Potential ash impact from Antarctic volcanoes: insights from deception Island's most recent eruption. Sci. Rep. 7:16534. doi: 10.1038/s41598-017-16630-9

Gonzalez, I., Hebel, I., and Jaña, R. (2013). "Ice-free areas and distribution Sanionia uncinata (Loeske) on places of South Shetland Islands, Antarctica," in Paper presented to the VII Congreso Latinoamericano de Ciencia Antártica (La Serena).

Grundmann, M., Ansell, S. W., Russell, S. J., Koch, M. A., and Vogel, J. C. (2007). Genetic structure of the widespread and common Mediterranean bryophyte Pleurochaete squarrosa (Brid.) Lindb. (Pottiaceae) - evidence from nuclear and plastidic DNA sequence variation and allozymes. Mole. Ecol. 16, 709-722. doi: 10.1111/j.1365-294X.2007.03181.x

Hebel, I., Galleguillos, C., Jana, R., and Dacasa-Rudinger, M. D. C. (2012). Early knowledge of Antarctica's vegetation: expanding past and current evidence. Rev. Chil. Hist. Nat. 85, 409-418. doi: 10.4067/S0716-078X2012000400004 
Hebel, I., and Rojas, G. (1999). "Estudio preliminar del contenido aerobiológico de la atmósfera de la Península Antártica y su relación con el ecosistema," in Paper presented to the Reunión Chilena de Investigación Antártica, Santiago, 12-13 Agosto 1999.

Hedenas, L. (2012). Global phylogeography in Sanionia uncinata (Amblystegiaceae: Bryophyta). Bot. J. Linn. Soc. 168, 19-42. doi: 10.1111/j.1095-8339.2011.01189.x

Jones, T. C., Hogg, I. D., Wilkins, R. J., Green, T. G. A. (2015). Microsatellite analyses of the Antarctic endemic lichen Buellia frigida Darb. (Physciaceae) suggest limited dispersal and the presence of glacial refugia in the Ross Sea region. Polar Biol. 38, 941-949. doi: 10.1007/s00300015-1652-9

Kato, K., Arikawa, T., Imura, S., and Kanda, H. (2013). Molecular identification and phylogeny of an aquatic moss species in Antarctic lakes. Polar Biol. 36, 1557-1568. doi: 10.1007/s00300-013-1373-x

Kimmerer, R. W. (1991). Reproductive ecology of Tetraphis pellucida. II. Differential success of sexual and asexual propagules. Bryologist 94, 284-288. doi: $10.2307 / 3243966$

Larraín, J. (2007). Adiciones a la flora de musgos de la isla grande de chiloe, chile. Gayana. Botánica 64, 7-23. doi: 10.4067/S0717-66432007000100002

Lewis Smith, R. I. (1984). Colonization and recovery by cryptogams following recent volcanic activity on Deception Island, South Shetland Islands. Br. Antarct. Surv. Bull. 62, 25-51.

Mantel, N. (1967). The detection of disease clustering and a generalized regression approach. Cancer Res. 27, 209-220.

Marshall, W. A., and Convey, P. (1997). Dispersal of moss propagules on Signy Island, maritime Antarctic. Polar Biol. 18, 376-383. doi: $10.1007 / \mathrm{s} 003000050203$

Martí, J., Vila, J., and Rey, J. (1996). Deception Island (Bransfield Strait, Antarctica): An Example of a Volcanic Caldera Developed by Extensional Tectonics. London: Geological Society, Special Publications, 253-65.

McDaniel, S. F., and Miller, N. G. (2000). Winter dispersal of bryophyte fragments in the Adirondack Mountains, New York. Bryologist 103, 592-600. doi: 10. 1639/0007-2745(2000)103[0592:WDOBFI]2.0.CO;2

Muñoz, J., Felicísimo, A. M., Cabezas, F., Burgaz, A. R., Martinez, I. (2004). Wind as a long-distance dispersal vehicle in the Southern Hemisphere. Science 304, 1144-1147. doi: 10.1126/science. 1095210

Navas, A., Lopez-Martinez, J., Casas, J., Machin, J., Jose Duran, J., Serrano, E., et al. (2008). Soil characteristics on varying lithological substrates in the South Shetland Islands, maritime Antarctica. Geoderma 144, 123-139. doi: 10.1016/j.geoderma.2007.10.011

Ochyra, R., Lewis Smith, R. I., and Bednarek-Ochyra, H. (2008). The Illustrated Moss Flora of Antarctica. Cambridge: Cambridge University Press.

Page, R. D. M. (1996). TreeView: an application to display phylogenetic trees on personal computers. Comput. Appl. Biosci. 12, 357-358.

Parnikoza, I., Rozhok, A., Convey, P., Veselski, M., Esefeld, J., Ochyra, R., et al. (2018). Spread of Antarctic vegetation by the kelp gull: comparison of two maritime Antarctic regions. Polar Biol. 41, 1143-1155. doi: 10.1007/s00300-018-2274-9

Paun, O., and Schönswetter, P. (2012). Amplified fragment length polymorphism (AFLP) - an invaluable fingerprinting technique for genomic, transcriptomic and epigenetic studies. Methods Mol. Biol. 862, 75-87. doi: 10.1007/978-1-61779-609-8_7

Peakall, R., and Smouse, P. E. (2006). GENALEX 6: genetic analysis in Excel. Population genetic software for teaching and research. Mole. Ecol. Notes 6, 288-295. doi: 10.1111/j.1471-8286.2005.01155.x

Peakall, R., and Smouse, P. E. (2012). GenAlEx 6.5: genetic analysis in Excel. Population genetic software for teaching and research-an update. Bioinformatics 28, 2537-2539. doi: 10.1093/bioinformatics/ bts 460

Pfeiffer, M., Mascayano, C., and Aburto, F. (2010). Soils of Chilean Patagonia in Glacial and periglacial environments. Eurasian Soil Sci. 43, 1430-1438. doi: 10.1134/S106422931013003X

Pritchard, J. K., Stephens, M., and Donnelly, P. (2000). Inference of population structure using multilocus genotype data. Genetics 155, 945-959.

Rolph, G., Stein, A., and Stunder, B. (2017). Real-time environmental applications and display sYstem: READY. Environ. Model. Softw. 95, 210-228. doi: 10.1016/j.envsoft.2017.06.025
Sambrook, J., and Russell, D. W. (2001). Molecular Cloning: A Laboratory Manual, $3 r d$ Edn. New York, NY: Cold Spring Harbor Laboratory Press.

Schlueter, P. M., and Harris, S. A. (2006). Analysis of multilocus fingerprinting data sets containing missing data. Mole. Ecol. Notes 6, 569-572. doi: 10.1111/j.1471-8286.2006.01225.x

Selkirk, P. M., Skotnicki, M., Adam, K. D., Connett, M. B., Dale, T., Joe, J. W., et al. (1997). Genetic variation in Antarctic populations of the moss Sarconeurum glaciale. Polar Biol. 18, 344-350. doi: 10.1007/s003000050198

Selkirk, P. M., Skotnicki, M. L., Ninham, J., Connett, M. B., and Armstrong, J. (1998). Genetic variation and dispersal of Bryum argenteum and Hennediella heimii populations in the Garwood Valley, southern Victoria Land, Antarctica. Antarct. Sci. 10, 423-430. doi: 10.1017/S0954102098000510

Skotnicki, M. L., Ninham, J. A., and Selkirk, P. M. (1998a). High levels of RAPD diversity in the moss Bryum argenteum in Australia, New Zealand, and Antarctica. Bryologist 101, 412-421.

Skotnicki, M. L., Ninham, J. A., and Selkirk, P. M. (1999a). Genetic diversity and dispersal of the moss Sarconeurum glaciale on Ross Island, East Antarctica. Mole. Ecol. 8, 753-762.

Skotnicki, M. L., Selkirk, P. M., and Beard, C. (1998b). RAPD profiling of genetic diversity in two populations of the moss Ceratodon purpureus in Victoria Land, Antarctica. Polar Biol. 19, 172-176.

Skotnicki, M. L., Selkirk, P. M., and Ninham, J. A. (1998c). RAPD analysis of genetic variation and dispersal of the moss Bryum pseudotriquetrum from Southern Victoria Land, Antarctica. Polar Biol. 20.121-126.

Skotnicki, M. L., Selkirk, P. M., and Ninham, J. A. (1999b). RAPD analysis of genetic variation and dispersal of the moss Bryum argenteum in Ross Island and Victoria Land, Antarctica. Polar Biol. 21.417-422.

Smellie, J. L., Pankhurst, R. J., Thomson, M. R., and Davies, R. E. (1984). The Geology of the South Shetland Island: IV. Stratigraphy, Geochemistry and Evolution. British Antarctic Survey Reports 87, Cambridge. p. 84.

Smith, R. I. L., and Convey, P. (2002). Enhanced sexual reproduction in bryophytes at high latitudes in the maritime Antarctic. J. Bryol. 24, 107-117. doi: 10.1179/037366802125000962

Sollman, P. (2015). The genus Bryoerythrophyllum (Musci, Pottiaceae) in Antarctica. Polish Bot. J. 60, 19-25. doi: 10.1515/pbj-2015-0004

Stein, A. F., Draxler, R. R., Rolph, G. D., Stunder, B. J. B., Cohen, M. D., and Ngan, F. (2015). Noaa's hysplit atmospheric transport and dispersion modeling system. Bull. Am. Meteorol. Soc. 96, 2059-2077. doi: 10.1175/BAMS-D-14-00110.1

Torres-Mellado, G. A., Jana, R., and Casanova-Katny, M. A. (2011). Antarctic hairgrass expansion in the South Shetland archipelago and Antarctic Peninsula revisited. Polar Biol. 34, 1679-1688. doi: 10.1007/s00300-011-1099-6

Van Der Velde, M., and Bijlsma, R. (2000). Amount and structure of intra- and interspecific genetic variation in the moss genus Polytrichum. Heredity 85, 328-337. doi: 10.1046/j.1365-2540.2000.00762.x

Vekemans, X., Beauwens, T., Lemaire, M., and Roldan-Ruiz, I. (2002). Data from amplified fragment length polymorphism (AFLP) markers show indication of size homoplasy and of a relationship between degree of homoplasy and fragment size. Mole. Ecol. 11, 139-151. doi: 10.1046/j.0962-1083.2001. 01415.x

Vos, P., Hogers, R., Bleeker, M., Reijans, M., Vandelee, T., Hornes, M., et al. (1995). AFLP - a new technique for dna-fingerprinting. Nucleic Acids Res. 23, 4407-4414. doi: 10.1093/nar/23.21.4407

Weising, K., Nybom, H., Wolff, K., and Kahl, G. (2005). DNA Fingerprinting in Plants Principles, Methods, and Applications Boca. Raton: Taylor \& Francis Group.

Conflict of Interest Statement: The authors declare that the research was conducted in the absence of any commercial or financial relationships that could be construed as a potential conflict of interest.

Copyright (C) 2018 Hebel, Dacasa Rüdinger, Jaña and Bastias. This is an open-access article distributed under the terms of the Creative Commons Attribution License (CC $B Y)$. The use, distribution or reproduction in other forums is permitted, provided the original author(s) and the copyright owner(s) are credited and that the original publication in this journal is cited, in accordance with accepted academic practice. No use, distribution or reproduction is permitted which does not comply with these terms. 